\title{
EVALUASI DAMPAK PENYALURAN PEMBIAYAAN MIKRO SYARIAH PADA KESETARAAN, KEADILAN GENDER DAN INKLUSI SOSIAL
}

\author{
Faiqul Hazmi $^{1}$ \& Zahrotun Nafisah $^{2}$ \\ ${ }^{1 \& 2}$ Universitas Islam Nahdlatul Ulama Jepara \\ Email :faiqulhazmi@unisnu.ac.id
}

\begin{abstract}
ABSTRAK
Pembiayaan mikro mempunyai manfaat besar terhadap kesetaraan dan keadilan gender antara lakilaki dan perempuan, (1) Secara finansial berdampak pada peningkatan kepemilikan aset individual pada perempuan, meningkatnya nilai tawar perempuan dalam pengambilan keputusan berhubungan penggunaan pembiayaan dan pendapatan. (2) Non-finansial, menjadikan perempuan mempunyai akses dan kontrol terhadap sumber daya intangible seperti informasi dan pengaruhnya terhadap lingkungan guna meningkatkan perannya dalam sosial kemasyarakatan serta rasa percaya diri. Namun kebijakan pembiayaan pada lembaga keuangan belum sepenuhnya memihak pada keadilan gender, pemikiran ini didasarkan pada hasil penelitian, (1) Apabila dilakukan perbandingan aksesibilitas lakilaki dan perempuan jumlah laki-laki lebih banyak dibandingkan perempuan pada pembiayaan mikro individual. Seharusnya ada regulasi yang memberikan akses lebih mudah bagi perempuan untuk mendapatkan pembiayaan, karena dalam kondisi bersaing, perempuan relatif kalah dibandingkan lakilaki. (2) Adanya paradoks dimana perempuan dianggap sebagai penabung yang baik mampu secara rutin menyisihkan penghasilannya namun pada pembiayaan semakin besar nilai nominalnya semakin sedikit porsi perempuan dibandingkan laki-laki. (3) Sulitnya data pilah gender, informasi aksesibilitas pembiayaan berdasarkan perempuan dan laki-laki tidak bisa dengan mudah didapatkan, hal tersebut menunjukkan bahwa membahas pembiayaan berdasarkan gender belum menjadi mainstream dan kepentingan publik. (4) Pembiayaan mikro semakin memperberat beban perempuan, selain bertanggungjawab pada pekerjaan rumah tangga, di tambah mencukupi kebutuhan keluarga.
\end{abstract}

Kata Kunci : Dampak, Lembaga Keuangan Mikro, Gender, Inklusi Sosial.

\begin{abstract}
Microfinance has enormous benefits for gender equity for men and women. First, financially, it has an impact on increasing (1) Ownership of individual assets in women, (2) Increasing women's bargaining value in making decisions related to the use of financing and income. Second, nonfinancial, it makes women have access and control over intangible resources such as information and their effects on the environment so that they can increase their role. However, financing policies in financial institutions are not fully in favor of gender equity. It is based on research results (1) If a comparison is made of the accessibility of men and women, the number of men is greater than women in individual microfinance due to the role of men who are more prioritized in micro financing, there should be regulations that provide easier access for women to get financing due to competitive conditions, women are relatively inferior to men. (2) There is a paradox where women are considered to be good savers who are able to routinely set aside their income, but on the one hand, the greater the nominal value of financing, the smaller the proportion of women compared to men. (3) The difficulty of gender disaggregated data. The information on the accessibility of financing based on gender cannot be easily obtained. It shows that discussing gender-based financing does not get public interest (4) Microfinance adds to the burden on women. Apart from being responsible for household chores, women have duties to suffice family needs, which should be the responsibility of the head of the family.
\end{abstract}

Keywords : Impact, Microfinance Institutions, Gender, Social Inclusion. 


\section{PENDAHULUAN}

Marjinalisasi dan pemiskinan masyarakat berdasar gender dan ekslusi sosial adalah bentuk dari ketidakadilan, perlakuan dilakukan dengan cara diskriminasi yang bersumber pada keyakinan gender dan eksklusi sosial. Diskriminasi berarti setiap pembedaan, pengucilan, atau pembatasan yang di buat atas dasar jenis kelamin dan status sosial, yang mempunyai tujuan mengurangi atau menghapus pengakuan, penikmatan atau penggunaan hak-hak asasi manusia dan kebebasan-kebebasan pokok di bidang politik, ekonomi, dan lain-lain. Meskipun Gender Indeks Pembangunan (GDI) dan Pengukuran Pemberdayaan Gender (GEM) menunjukkan peningkatan tren dalam beberapa tahun terakhir. Namun keadilan gender dalam akses pembiayaan dan modal masih belum jelas. Kebijakan pembiayaan pada lembaga keuangan belum memihak pada keadilan gender khususnya perempuan. Pemikiran ini didasarkan pada fakta, (1) Dalam kondisi bersaing, perempuan relatif kalah dibandingkan laki-laki, karenanya harus ada regulasi yang memberikan akses lebih mudah bagi perempuan untuk mendapatkan pembiayaan. (2) Informasi aksesibilitas pembiayaan berdasarkan gender sulit didapatkan, hal tersebut menunjukkan bahwa membahas pembiayaan berdasarkan gender belum menjadi mainstream dan kepentingan publik. (3) Apabila dilakukan perbandingan antara aksesibilitas laki-laki dan perempuan jumlah laki-laki lebih banyak dibandingkan perempuan. (4) Pembiayaan mikro semakin memperberat beban perempuan, selain bertanggungjawab pada pekerjaan rumah tangga, perempuan mempunyai tugas tambahan mencukupi kebutuhan keluarga yang seharusnya tanggung jawab kepala keluarga. (5) Perempuan menghadapi triple burden of women, yaitu perempuan harus melakukan tiga fungsi ganda berupa reproduksi, produksi dan sosial di masyarakat. Sehingga selayaknya penyaluran pembiayaan mikro perlu mempertimbangkan waktu para perempuan yang terbatas karena berbagai aktivitas domestik rumah tangga.

Eksklusi keuangan merupakan pengunci bagi masyarakat miskin yang didominasi oleh perempuan untuk memperoleh akses keuangan. Eksklusi keuangan menjadi hambatan bagi masyarakat untuk bisa keluar dari kemiskinan, sehingga dibutuhkan terobosan untuk menghasilkan kehidupan ekonomi yang inklusif. Sistem layanan keuangan inklusif sejatinya merupakan usaha untuk menciptakan karakter kehidupan ekonomi yang tidak hanya mengakomodasi kalangan berada, namun juga memihak kalangan berpenghasilan rendah dan miskin (Rodoni, Nengsih \& Suptiyadi, 2012). Eksklusifitas sosial berikut turunanya berupa eksklusifitas pelayanan keuangan dapat, (1) Menutup peluang masyarakat untuk turut serta memupuk aset, sehingga tidak dapat meningkatkan kesejahteraanya. (2) Menyebabkan inefisiensi dalam transaksi pembayaran. (3) Menghambat pertumbuhan Dana Pihak Ketiga (DPK). (4) Menyebabkan Shadow Economy atau transaksi ekonomi yang tidak tercatat akan semakin besar sehingga rawan menimbulkan tindak pidana pencucian uang dan pendanaan terorisme. (5) Eksklusifitas dapat memperlebar kesenjangan sosial, tidak mendukung penurunan kemiskinan dan pertumbuhan ekonomi. Karenanya perlu pelayanan yang inklusif melalui penghapusan berbagai hambatan yang institusional, hambatan akses individu oleh kelompok marjinal, perempuan, difabel terhadap berbagai peluang pembangunan termasuk pelayanan keuangan mikro.

Model penilaian kinerja Lembaga Keuangan Mikro (LKM) yang selama ini terfokus kepada Indikator Keuangan 
berupa sustainibility (keberlangsungan usaha), profitabilitas (Keuntungan) serta Jangkauan (outreach) dalam bentuk kuantitatif berupa angka-angka yang tidak mempunyai pembelaan kepada kesamaan hak antara perempuan dan laki-laki serta inklusi sosial memerlukan adanya evaluasi dalam penyaluran serta kepentingan terhadap keadilan gender dan inklusi sosial pada penyaluran pembiayaan mikro. Penelitian ini melakukan upaya untuk mengevaluasi indikator-indikator keberhasilan Lembaga Keuangan Mikro Syariah yang belum berpihak pada kesetaraan gender dan inklusi sosial dan justru berpotensi berdampak pada semakin besarnya ketimpangan perlakuan berdasar gender serta eklusifisme sosial. Penelitian ini juga berupaya memberikan indikatorindikator baru kinerja Lembaga Keuangan Mikro Syariah (LKMS) dengan memasukkan unsur kesetaraan dan keadilan gender serta inklusi sosial Gender Equality and Social Inclusion (GESI) didalamnya.

\section{TINJAUAN PUSTAKA}

Lembaga Keuangan Mikro Syariah beroperasi menggunakan prinsip hukum Islam yang didalamnya mengandung pesan tentang keadilan, keseimbangan serta maslahah dalam kehidupan berekonomi. Sebagai agama yang menjunjung tinggi nilai keadilan dan persamaan mengandung prinsip-prinsip keadilan. Laki-laki dan perempuan samasama sebagai hamba, khalifah di bumi (Khalifatullah Fil Ard), Laki-laki dan perempuan sama-sama berpotensi untuk meraih prestasi optimal (Suhra, 2013) dalam literasi yang lain Prof. Dr. Nasaruddin Umar dalam (Kusdarini, 2010) menyatakan, (1) Laki-laki dan perempuan Sama-sama sebagai hamba. (2) Laki-laki dan perempuan sebagai khalifah di bumi. (3) Laki-laki dan perempuan menerima perjanjian primordial yaitu laki-laki dan perempuan sama-sama menyatakan ikrar ketuhanan yang sama di hadapan tuhan sebelum kelahiranya (Q.S. Al-A'raf ayat 172). (4) Adam dan hawa, terlibat secara aktif dalam drama kosmis yakni cerita tentang keadaan adam dan pasangannya di surga sampai keluar ke bumi, selalu menekankan kedua belah pihak secara aktif dengan menggunakan kata ganti untuk dua orang yakni kata ganti untuk adam dan hawa, seperti dapat dilihat dalam beberapa kasus berikut ini : keduanya diciptakan di surga dan memanfaatkan fasilitas surga (Q.S. AlBaqarah ayat 35). (5) Laki-laki dan perempuan sama-sama berpotensi meraih prestasi.

Lembaga Keuangan Mikro (LKM) oleh OJK di definisikan sebagai Lembaga Keuangan yang didirikan untuk memberikan jasa pengembangan usaha serta pemberdayaan masyarakat, melalui pinjaman, pembiayaan usaha, pengelolaan simpanan, maupun pemberian jasa konsultasi pengembangan usaha dalam skala mikro kepada anggota serta masyarakat, yang tidak hanya sematamata mencari keuntungan. (Suryanto \& Zaenal, 2015) LKM yang beroperasi menggunakan prinsip syariah dalam operasionalnya disebut Lembaga Keuangan Mikro Syariah (LKMS) Penilaian kinerja pembiayaan mikro syariah pada LKMS masih terfokus kepada dua penilaian kriteria kinerja, yaitu : (1) Indikator keuangan (Financial Performance), Indikator keuangan mencakup kualitas portofolio, serta kelayakan keuangan. (2) Indikator jangkauan (outreach) mencakup pertumbuhan capaian pembiayaan, klien, staf, tabungan serta deposito. Secara kuantitatif semakin besar dan luas jangkauan ketersebaran nasabah maka LKMS dinilai mempunyai kinerja yang baik. LKM termasuk didalamnya LKMS selama ini fokusnya terdapat pada kuantitas penyaluran bukan kualitas 
dampak yang ditimbulkan. (Robinson, 2001)

Sebagai lembaga keuangan yang bernafaskan Islam selayaknya mengacu pada dua koridor dasar yaitu Al-Qur'an dan Sunah Nabi. Implementasi keadilan gender perspektif Al-Qur'an melahirkan adanya keadilan dalam pilar keuangan syariah dimana terdapat keadilan dan kesamaan hak dalam kesempatan mendapatkan layanan keuangan serta kesempatan untuk mendapatkan akses layanan keuangan guna meningkatkan kesejahteranya, hal ini didukung oleh paper (Hussain et al., 2019). Keadilan gender (Gender Equity) dan kesetaraan gender (Gender Equality) mengandung makna bahwa "Semua orang dari segala umur dan jenis kelamin memiliki kesempatan sama untuk berhasil dalam hidup". Manusia tidak bisa memilih terlahir laki-laki atau perempuan. Karena itu kesetaraan dan keadilan gender meliputi hak asasi manusia serta merujuk pada kesamaan hak, tanggungjawab, kesempatan, perlakuan, dan penilaian bagi kaum lelaki dan perempuan. Gender merujuk pada pembedaan dan relasi sosial antara perempuan dan laki-laki, di dalam dan antar budaya, serta berubah dari waktu ke waktu. Peningkatan keadilan gender adalah tentang penjaminan atas hasil yang sama dan bagian yang sama bagi laki-laki dan perempuan sehingga semua orang diperlakukan sesuai dengan martabat kemanusiaan dan mendapat kesempatan untuk berkembang secara optimal menuju kualitas hidup yang lebih baik bagi semua orang. Contoh diskriminasi gender dalam hal keuangan adalah mengutamakan anggota keluarga laki-laki untuk berhubungan dengan lembaga keuangan dengan alasan laki-laki dianggap lebih kuat dalam berurusan dengan lembaga keuangan. Perempuan di banyak negara seringkali diabaikan peranya dan menjadikan perempuan peminjam kelas 2 (dua) setelah laki-laki. (Arunachalam, 2007).

Inklusi sosial adalah upaya menempatkan martabat dan kemandirian individu sebagai modal utama menuju kualitas hidup ideal. Inklusi sosial dipahami sebagai upaya untuk menghapus berbagai hambatan yang institusional, memperluas berbagai hambatan akses individu dan kelompok yang terpinggirkan (termasuk kelompok difabel) terhadap berbagai peluang pembangunan. Lawan kata inklusi sosial adalah eksklusi sosial yang berarti terdapat pembatasan terhadap orang tertentu berbasis gender, status sosial dan lain-lain. Eksklusi sosial merujuk pada sekelompok orang miskin, menganggur serta kurang beruntung yang tersingkir atau disingkirkan secara sistem dari kehidupan normal masyarakat. Eksklusi sosial merupakan proses peminggiran sosial beberapa kelompok yang didiskriminasikan berdasarkan etnis, ras, agama, orientasi seksual, kasta, keturunan, gender, usia, kecacatan, penyakit HIV, buruh atau masyarakat migran atau berdasarkan lokasi tempat mereka tinggal. (Sain et al., 2016). Dimensi eksklusi sosial dapat dibagi kedalam beberapa dimensi, (1) Individual : dicirikan peminggiran karena faktor kekurangan fisik, pendidikan, kejadian pada kehidupan individu, orangtua tunggal. (2) Dimensi Sosial : ketidaksamaan dan ketidakadilan lokasi, gender, usia, etnik, praktek budaya. (3) Dimensi Ekonomi : masalah keuangan, pengangguran, kelangkaan sumberdaya. (4) Sosial-Ekonomi-Politik : Kemiskinan, Marginalisasi politik, aktivitas berpolitik terbatas. (5) Institusi dan Organisasi : Peraturan, kebijakan dan proses. (Nurdin, 2013) 
Tabel 1. Dimensi Peminggiran Sosial

\begin{tabular}{lll}
\hline \multicolumn{1}{c}{$\begin{array}{c}\text { Dimensi Peminggiran } \\
\text { Sosial }\end{array}$} & \multicolumn{1}{c}{ Ciri-Ciri } & \multicolumn{1}{c}{ Sumber } \\
\hline Individual & $\begin{array}{l}\text { Kesehatan fisik, pendidikan, kejadian pada } \\
\text { kehidupan individu, orang kurang upaya, } \\
\text { ibu tunggal }\end{array}$ & $\begin{array}{l}\text { (Burchardt et al., 1999; Pierson, } \\
\text { 2002; GJ. 1999; Suharto, 2009) }\end{array}$ \\
\hline Sosial & $\begin{array}{l}\text { Ketidaksamaan dan ketidakadilan, lokasi, } \\
\text { gender, usia, etnik, praktek budaya }\end{array}$ & (Levitas, 1996; Sheppard, 2006) \\
\hline Ekonomi & $\begin{array}{l}\text { Masalah keuangan, pengangguran, } \\
\text { kelangkaan sumber }\end{array}$ & (Bonner, 2006) \\
\hline Sosial-ekonomi-politik & $\begin{array}{l}\text { Kemiskinan, marginalisasi politik, } \\
\text { aktivitas berpolitik terbatas. }\end{array}$ & $\begin{array}{l}\text { (Batsleer\&Humpries, 2000; } \\
\text { Dowling, 1999) }\end{array}$ \\
\hline Institusi dan organisasi & Peraturan, kebijakan dan proses & (Beall \& Piron, 2005) \\
\hline
\end{tabular}

Sumber : Nurdin, (2013)

Penelitian (Rahman et al., 2017) mengungkap keuangan mikro memiliki dampak positif pada pemberdayaan perempuan di Bangladesh. Pemberdayaan perempuan melalui keputusan pendidikan anak, mengunjungi kerabat, keputusan tentang perawatan medis, penggunaan kontrasepsi, membeli barang-barang pribadi, membeli barang rumah tangga, kendali pendapatan, serta merasa aman dan kuat dalam keluarga meningkat secara nyata setelah mengambil fasilitas pembiayaan mikro. Sebagian besar perempuan mengalami beberapa tingkat pemberdayaan dengan kesempatan mendapatkan program pembiayaan mikro. Pembiayaan mikro berpotensi memiliki dampak kuat pada pemberdayaan perempuan serta akan menguatkan basis keuangan perempuan dan meningkatkan kontribusi ekonomi bagi keluarga dan komunitas mereka; sehingga mampu meningkatkan daya tawar dan pengambilan keputusan, meningkatkan kesejahteraan, mengurangi subordinasi dan memperkuat suara perempuan.

LKM mampu (1) Meningkatkan pendapatan penerima pinjaman, di Indonesia pendapatan meningkat $12,9 \%$ vs $3 \%$ (non-peminjam), Bangladesh: $29.3 \%$ vs $22 \%$ (non-peminjam), SriLanka: $15.6 \%$ vs $9 \%$ (non-peminjam) dan di India $46 \%$ vs 24\% (non-peminjam). (Rantetana, 2011) (2) Meningkatkan kemampuan rumah tangga mempertahankan kesejahteraannya dalam jangka panjang. (3) Meningkatkan konsumsi kalori. (4) Kondisi nutrisi anak yang lebih baik (Rantetana, 2011). Keputusan fasilitasi kredit mikro kelompok juga berdampak terhadap laba perusahaan dan kemampuan bayar penerima kredit (Dwipasari, 2016). Hal ini berarti dengan tambahan modal yang diperoleh dari pinjaman lunak membuat usaha beroperasi lebih efisien. Umumnya usaha mikro yang mendapat pelayanan keuangan pendapatannya meningkat secara signifikan per bulan rata-rata $87,34 \%$. (Syukur, 2002). Penelitian lainya oleh (Syukri Lukman, 2008) menemukan Pertama dampak sosial pembiayaan mikro diantaranya, (1) Meningkatnya partisipasi wanita dalam berusaha. (2) Meningkatnya tingkat pendidikan anggota keluarga. (3) Meningkatnya jaringan sosial. Meningkatnya jaringan pengusaha. (5) Meningkatkan pengetahuan masyarakat tentang lembaga keuangan. Mendorong masyarakat berwirausaha. Kedua Dampak di bidang ekonomi, (1) Bertumbuhnya jumlah usaha mikro. (2) Meningkatnya skala usaha. (3) Meningkatnya penyerapan tenaga kerja. 
(4) masyarakat. Meningkatnya

pertumbuhan ekonomi

penghasilan Mempercepat lokal. Meningkatkan mobilasi dana masyarakat.

Sementara kasus negatif dikemukakan oleh (Rachmina, 2009) kebijakan pembiayaan tidak memihak pada perempuan dikarenakan proporsi jumlah peminjam laki-laki lebih banyak dibandingkan dengan peminjam perempuan serta sulitnya akses informasi peminjam perempuan. Perempuan memiliki tingkat finansial stress lebih tinggi dibandingkan laki-laki, perempuan lebih mungkin mengalami finansial stress dibandingkan laki-laki. Tanpa adanya payung aturan dan perlindungan yang lebih baik perempuan akan lebih rentan dalam mengalami finansial stress. Ditambahkan (Asmorowati, 2007) Kredit mikro justru semakin melegitimasi beban ganda perempuan selain bertanggungjawab pada pekerjaan domestik, perempuan mempunyai beban mencukupi kebutuhan keluarga yang seharusnya adalah tanggung jawab laki-laki. Program kredit mikro justru semakin memperkuat triple burden of women, yaitu fungsi reproduksi, produksi dan sosial di masyarakat. Sedangkan (Setyari, 2012) Menyatakan rata-rata pendidikan anak dari penerima pembiayaan mikro mempunyai tingkat pendidikan yang lebih rendah dibandingkan yang tidak. Kedua Penelitian ini berfokus pada dampak pembiayaan mikro pada beban perempuan serta pendidikan anak namun tidak menambah variabel lain seperti inklusi sosial serta indikator keberhasilan program.

(Bishwakarma, 2017) Menyatakan bahwa keuangan mikro terbukti menjadi alat yang efektif untuk mengurangi kemiskinan. Namun tidak cukup menembus strata masyarakat yang lebih miskin. Tantangan utama untuk inklusi sosial adalah kemiskinan, keterpencilan dan sosial-budaya. Langkah yang harus dilakukan adalah dengan tujuan perubahan inklusi sosial melalui Institutional Reform/Innovation, dan Transformative Reform on Public Policy. Inovasi kelembagaan transformatif membantu mengatasi ketidaksetaraan dan kerugian struktural, dan untuk memberdayakan aktor yang lebih lemah. Terdapat pengaruh signifikan jumlah pembiayaan serta simpanan terhadap pendapatan rumah tangga dan pengeluaran konsumsi rumah tangga. (Addury, 2019) Oleh karenanya sangat diperlukan adanya inklusi keuangan secara khusus dan lebih luas kepada inklusi sosial agar masyarakat dapat ikut berpartisipasi pada pelayanan sosial dan keuangan. Kehidupan yang layak merupakan hak bagi semua warga negara termasuk diantaranya perempuan, penyandang cacat dan penyandang masalah sosial lainya. Maka seharusnya negara dan semua komponen masyarakat mengeluarkan kebijakan-kebijakan yang adil bagi semua warga negara. Secara konseptual, kebijakan-kebijakan tersebut disebut sebagai kebijakan yang inklusif. Pelayanan pembiayaan mikro dengan imbalan yang rendah melalui lembaga keuangan mikro semestinya dapat disediakan kepada seluruh masyarakat sebagai sarana meningkatkan kesejahteraanya tanpa terkecuali.

$$
\text { Penilaian kinerja Lembaga }
$$

Keuangan Mikro (LKM) sebagian besar terfokus kepada dua penilaian kriteria kinerja, yaitu : (1) Indikator keuangan dan jangkauan (outreach). Indikator keuangan mencakup kualitas portofolio, leverage, capital adequacy ratio, produktivitas, efisiensi, profitabilitas, dan kelayakan keuangan, sehingga diharapkan kemampuan LKM tersebut akan mampu menopang sustainibility atau keberlangsungan lembaga keuangan mikro ke depan serta mampu menarik investor untuk ikut berpartisipasi. (2) Indikator jangkauan (outreach) mencakup capaian klien dan staf, pinjaman, tabungan 
serta deposito. Secara kuantitatif semakin besar dan luas jangkauan dan ketersebaran nasabah maka lembaga keuangan mikro dinilai mempunyai kinerja yang baik. Hal tersebut menjadi penyebab indikator kualitatif non keuangan kurang menarik pada LKM. Penilaian dalam bentuk angka saja sebagaimana tersebut tidaklah salah, namun terdapat kekurangan jika merujuk pada pengertian Lembaga Keuangan Mikro (LKM) sebagai lembaga yang melakukan kegiatan penyediaan jasa keuangan tidak hanya semata-mata untuk mengejar keuntungan. LKM juga bertanggung jawab memberdayakan masyarakat yang membutuhkan pelayananya tanpa membeda-bedakan dan melakukan pembatasan-pembatasan. Untuk mencapai hal tersebut diperlukan adanya indikator tambahan sebagai acuan pencapaian kinerja LKM yang mengakomodasi kepentingan Gender Equality and Social Inclusion "GESI".

Namun diantara besarnya keberhasilan terdapat pula beberapa hal negative diantaranya adalah pihak LKM membebankan imbalan yang tergolong tinggi kepada penerima kredit mikro, yaitu setara 1,5 flat atau $18 \%$ per tahun. Sehingga membebani perekonomian penerima kredit mikro. Alasannya pembiayaan mikro dipandang memiliki resiko yang tinggi. (Dwipasari, 2016) Rata rata pendidikan anak dari penerima pembiayaan mikro mempunyai tingkat pendidikan yang lebih rendah dibandingkan yang tidak (Setyari, 2012). Dalam hubunganya dengan Gender Equity Kebijakan pembiayaan tidak memihak bahwa proporsi jumlah peminjam laki-laki lebih banyak dibandingkan dengan peminjam perempuan (Rachmina, 2009). Perempuan mempunyai beban ganda dimana selain bertanggungjawab pada pekerjaan domestik, perempuan mempunyai beban untuk mencukupi kebutuhan keluarga yang seharusnya adalah tanggung jawab kepala keluarga
(Asmorowati, 2007). Terdapat tendensi perempuan memiliki tingkat finansial stress yang lebih tinggi dibandingkan lakilaki, dimana perempuan lebih mungkin mengalami finansial stress dibandingkan laki-laki. Tanpa adanya payung aturan dan perlindungan yang lebih baik tentu perempuan akan lebih rentan dalam mengalami finansial stress.

Pembiayaan yang diberikan pada perempuan akan berdampak positif pada pembiayaan mikro yang disalurkan LKMS pada perempuan menjadikan perempuan mempunyai akses atau kontrol terhadap aset dan sumber daya finansial yang berdampak pada berbagai berbagai aspek finansial, dan sosial baik dalam keluarga maupun bermasyarakat. Pertama Pembiayaan mikro yang disalurkan LKMS pada perempuan menjadikan perempuan mempunyai akses dan kontrol terhadap sumber daya yang bersifat intangible seperti informasi, pengaruhpengaruhnya terhadap lingkungan sehingga mampu meningkatkan peranya dalam sosial kemasyarakatan serta meningkatnya rasa percaya diri pada perempuan. Menempatkan perempuan pada posisi yang sama dalam mengakses serta berlindung dalam struktur hukum. Dengan pengelolaan kredit mikro yang diberikan kepada perempuan akan menjadi dasar bagi para perempuan untuk menghadapi ketidakadilan dalam kehidupan mereka. Pembiayaan mikro yang diterima oleh perempuan akan meningkatkan mereka dalam mengakses dan melakukan kontrol terhadap ruang politik. Adanya kesetaraan dalam pengambilan keputusan dalam keluarga meningkatkan kontrol perempuan terhadap tubuh mereka diukur dengan keikutsertaan perempuan dalam pengambilan keputusan dalam hal-hal yang penting dalam perkawinan mereka, seperti dalam : a) Keputusan mengenai anak (termasuk jumlah, jarak, atau bahkan penentuan jenis kelamin, dan cara 
membesarkannya). b) penggunaan Kontrasepsi dan aborsi. c) Berhubungan seksual dengan suami. d) Perempuan yang mempunyai akses terhadap finansial akan meningkatkan nilai tawar perempuan sehingga menurunkan kecenderungan untuk mengalami kekerasan dalam rumah tangga (domestic violence) karena keberanian mereka untuk melawan. e) Pembagian kerja (division of labour) istri dan suami. Budaya patriarki menyebabkan istri bertanggung jawab pada aktivitas domestik, seperti membesarkan anak, membersihkan rumah, memasak dan pekerjaan rumah tangga yang lain; sedangkan suami bertanggung jawab pada aktivitas produktif berkenaan dengan perolehan pendapatan. Adanya pembiayaan mikro yang diterima oleh perempuan akan menjadikanya mempunyai nilai tawar lebih untuk melakukan aktifitas-aktifitas produktif seperti usaha, dan kegiatan produktif lainya yang pada akhirnya akan mendorong para suami bersedia berbagi tugas domestik.

Kedua Secara finansial pembiayaan mikro berdampak pada peningkatan, (1) Kepemilikan aset individual pada perempuan, pembiayaan yang didapatkan dari lembaga keuangan digunakan untuk meningkatkan aset individual perempuan sehingga menjadi cadangan simpanan pada saat keluarga mengalami kesulitan ekonomi. Beberapa aset individual diantaranya adalah emas perhiasan yang digunakan perempuan. (2) Pembiayaan mikro yang diberikan kepada perempuan menjadikan nilai tawar perempuan meningkat dalam pengambilan keputusan yang berhubungan dengan penggunaan pembiayaan, seperti siapa yang mengontrol penggunaan uang, siapa yang mengelola usaha yang didukung oleh pembiayaan, siapa yang mengontrol pemasaran produk, dan siapa yang mengontrol penghasilan yang didapat dari usaha yang didukung pembiayaan. Pada usaha mikro yang mayoritas dijalankan oleh perempuan, dengan adanya akses pembiayaan mikro akan memperkuat kekuatan finansial perempuan sehingga berdampak pada kemampuan perempuan dalam mengakses dan mengkontrol tenaga kerja dan pendapatan. (3) Meningkatnya akses perempuan dalam memperoleh pendapatan juga akan meningkatkan kemampuan mereka untuk turut serta dalam pengambilan keputusan di keluarga. Dengan adanya akses terhadap pembiayaan, para perempuan mempunyai kesempatan yang setara bersama-sama dengan suami mereka mengambil keputusan untuk hal-hal yang penting dalam keluarga seperti pengalokasian keuangan rumah tangga, pendidikan anakanak mereka, dan berpartisipasi dalam kegiatan-kegiatan sosial kemasyarakatan yang memerlukan akses dana. Adanya pembiayaan yang diterima perempuan akan menjadikan adanya tambahan penghasilan yang diterima serta pada akhirnya akan menambahkan jumlah alokasi dana untuk pendidikan anak. Adanya tambahan alokasi dana pendidikan akan berdampak pada meningkatnya kemungkinan anak perempuan untuk melanjutkan sekolah. Budaya patriarki menyebabkan perempuan mempunyai usia sekolah yang lebih rendah daripada laki-laki dikarenakan budaya tersebut mendorong perempuan untuk terpaku pada aktifitas domestik rumah tangga. Pembiayaan mikro memungkinkan penerimanya untuk mempunyai standar konsumsi yang layak untuk meningkatkan kesejahteraanya serta lingkungan sekitarnya dikarenakan penerima pembiayaan mikro relatif dibawah kelayakan.

\section{METODE PENELITIAN}

Penelitian ini adalah penelitian evaluasi. Evaluasi dalam penelitian ini berupa evaluasi dampak penyaluran pembiayaan mikro pada lembaga keuangan mikro syariah (LKMS) dalam 
mendorong kesetaraan dan keadilan gender serta inklusi sosial. Alasan mengapa dampak suatu program dipelajari adalah untuk melihat apakah program tersebut betul-betul telah membawa perubahan sesuai yang diharapkan. Dampak sebagai konsekuensi jangka panjang dari suatu intervensi program yang berkaitan dengan pencapaian tujuan pelaksanaan program, baik yang bersifat positif maupun negatif, langsung maupun tidak langsung (directly or indirectly) dan diharapkan atau tidak diharapkan (intended or unintended). Jenis dan Pendekatan Penelitian ini menggunakan pendekatan kualitatif untuk menangkap dan menampilkan individualized outcomes dari para partisipan. Tempat penelitian ini adalah LKMS diwilayah kabupaten Jepara yang mempunyai karakteristik menyalurkan pembiayaan mikro dalam bentuk pembiayaan mikro individial dan pembiayaan mikro kelompok. Pemilihan informan dilakukan secara purposif dengan beberapa kriteria bertemu secara langsung dengan individu penerima pembiayaan mikro. Teknik pengumpulan data dilakukan dengan, (1) Observasi. (2) Wawancara. (3) Drawing self-portaits atau Menggambar potret diri. (4) Dokumen anggota pada LKMS. (5) dan Focus Group Discussion (FGD).

Teknik analisis data dimulai dengan mengorganisasikan data secara sistematis dan selengkap mungkin. selanjutnya peneliti melakukan koding, dengan membubuhkan kode-kode pada materi yang diperoleh. Koding dimaksudkan untuk dapat mengorganisasi dan mensistematisasi data secara lengkap, mendetil sehingga data dapat memunculkan gambaran tentang topik yang dipelajari. Setelah itu data dianalisis untuk mengidentifikasi pola pengalaman informan selama terlibat di dalam program, karakteristik pola partisipasi selama terlibat di dalam program dan pola perubahan yang terjadi pada informan.
Pengujian keabsahan data dalam penelitian ini, peneliti berusaha memenuhi empat standar tersebut dengan kredibilitas, transferabilitas, dependabilitas dan konfirmabilitas (Burhan, 2012).

\section{HASIL DAN PEMBAHASAN}

Hasil penelitian didapatkan bahwa Lembaga Keuangan Mikro Syariah (LKMS) melakukan penginputan data berdasarkan jenis kelamin, agama, dan penghasilan namun sistem informasi pada LKMS tidak terdapat akses yang mudah sebagai data pilah untuk mengetahui jumlah penerima pembiayaan berdasarkan laki-laki dan perempuan serta tidak ada petugas yang mampu melakukan sorting persentase berdasarkan data-data tersebut. Cara sorting hanya bisa dilakukan secara manual mendownload laporan kemudian memilahnya. Untuk mendapatkan jumlah penerima pembiayaan berdasarkan gender, agama, penghasilan harus dilakukan oleh tim teknologi informasi dari kantor pusat masing-masing LKMS kemudian memilahnya dengan cara manual. Berikut juga data mengenai Agama, dan penghasilan penerima pembiayaan. sedangkan untuk data penyandang disabilitas sama sekali tidak ada data mulai dari penginputan data. Hal tersebut menunjukkan bahwa membahas pembiayaan berdasarkan gender dan inklusi sosial belum menjadi mainstream (arus utama) serta kepentingan publik tidak ada usaha sistematis serta komitmen untuk memberikan proporsi penerima pembiayaan berdasarkan gender dan inklusi sosial.

Perempuan mempunyai porsi yang sangat besar pada pembiayaan ultra mikro yang didasarkan pada jumlah tabungan, keamanan kolektibilitas (rendahnya angka kemacetan pembiayaan) serta kemudahan kolektibilitas serta relatif lebih aman dibandingkan laki-laki. Hal tersebut senada dengan pernyataan (Saravia-Matus 
\& Saravia-Matus, 2012). Namun budaya patriarki secara tidak sadar menyusup sehingga perempuan dipersonifikasikan sebagai pihak yang rajin menabung dan sebagai pengelola keuangan rumah tangga sehingga selayaknya diprioritaskan pada pembiayaan ultra mikro yang kategori nilainya lebih rendah dibandingkan pembiayaan lainya dalam hal ini adalah pembiayaan mikro untuk usaha. Dalam hal ini dapat disimpulkan terdapat paradok dimana perempuan dianggap sebagai pihak yang rajin menabung dan berisiko rendah dalam hal kolektibilitas pembiayaan namun pada kenyataanya saat jumlah pembiayaan meningkat penerima manfaat pembiayaan pada perempuan justru mengalami penurunan dibandingkan laki-laki. Penjelasanya meskipun tidak secara sistematis dilakukan terdapat perbedaan perlakuan dalam pemilihan gender penerima pembiayaan mikro. Untuk pembiayaan kecil antara 1-5 juta diutamakan penerima pembiayaan adalah perempuan sedangkan diatas 5 juta diutamakan laki-laki dengan alasan laki-laki sebagai pihak yang bekerja, penanggung jawab atas pinjaman meskipun usahanya ditangani oleh perempuan serta kepemilikan agunan berada di tangan laki-laki.

Tabel 2. Data Persentase Penerima Pembiayaan Mikro

\begin{tabular}{lcc}
\hline \multirow{2}{*}{ Jenis Pembiayaan } & \multicolumn{2}{c}{ Jenis Kelamin } \\
\cline { 2 - 3 } & Perempuan & Laki-Laki \\
\hline Pembiayaan Ultra Mikro kurang dari 5 Juta & $62 \%$ & $38 \%$ \\
\hline Pembiayaan Mikro 5 Juta sampai 25 Juta & $41 \%$ & $59 \%$ \\
\hline Pembiayaan Mikro lebih dari 25 Juta sampai 50 Juta & $29 \%$ & $71 \%$ \\
\hline
\end{tabular}

Sumber : Data Olahan (2020)

Pada pembiayaan mikro tanggung renteng dikhususkan untuk perempuan guna mengentaskan mereka dari kemiskinan, melalui pembiayaan mikro tanggung renteng diharapkan, (1) Perempuan mempunyai peran aktif dalam mengatur keuangan rumah tangganya. (2) Melalui pembiayaan tanggung renteng pula perempuan dilatih untuk mampu
Beberapa percakapan hasil interview dengan informan manajer salah satu Baitul mal wat tamwil sebagai informan penelitian diantaranya adalah "Ya kalau peminjam keduanya baik laki-laki maupun perempuan datang kemari otomatis akan kami mintakan yang laki-laki sebagai peminjamnya sebagai penanggung jawab". Hal tersebut dilakukan dengan alasan tanggung jawab karena sebagian besar pada pembiayaan mikro pihak lakilaki mempunyai penghasilan yang lebih besar dari perempuan meskipun usaha yang didanai adalah milik perempuan. hasil lainya pada kasus kepemilikan jaminan ada pada laki-laki "Untuk memudahkan perikatan jaminan kami mengutamakan laki-laki meskipun usahanya dilakukan perempuan." Sedangkan budaya masyarakat masih mengutamakan kepemilikan aset atau jaminan kepada laki-laki. Hal tersebut menyebabkan penyaluran pembiayaan cenderung berada menguntungkan lakilaki dan melanjutkan kepemilikan aset atau jaminan tetap berada pada laki-laki. Pada hasil data tabel 2 menunjukkan bahwa semakin besar nominal pembiayaan porsi akses perempuan semakin menurun dibandingkan laki-laki.

mainkan peranya dalam mengorganisir kelompoknya. Namun terdapat beberapa kekurangan pada pembiayaan tanggung renteng. Diantaranya adanya subordinasi perempuan pada pembiayaan mikro tanggung-renteng dikarenakan semua anggotanya adalah perempuan dengan alasan perempuan mempunyai ikatan sosial yang lebih kuat daripada laki-laki 
serta kecenderungan lebih persuasif dalam penyelesaian pembiayaan bermasalah.

Hasil wawancara dengan officer dan dibenarkan pada saat Focus Group Discussion (FGD) kegiatan penelitian menyatakan bahwa perempuan dipilih diantaranya : karena, (1) Perempuan cenderung lebih bisa dikendalikan daripada laki-laki, dalam pembiayaan kelompok dibuktikan dengan kesediaan untuk mentaati peraturan kelompok berupa menghadiri pertemuan center meeting setiap minggu. (2) Mayoritas perempuan bersedia untuk membantu pihak lembaga untuk keberlangsungan kelompok dengan bersedia menagih anggota-anggota yang ada didalam kelompok yang mengalami kemacetan, bahkan bersedia berpartisipasi dalam membantu menggalang (menalangi) angsuran yang mengalami kemacetan yang mana hal tersebut tidak mungkin bersedia dilakukan oleh laki-laki. (3) Perempuan dipersonifikasikan sebagai pihak yang beraktifitas dirumah (domestik) serta mempunyai banyak waktu luang dan laki-laki sebagai kepala keluarga yang bekerja diluar rumah.

Analisis gender dapat dilakukan dengan berbagai teori diantaranya Handayani dan Sugiarti (2009) dalam (Sari \& Margowati, 2016) model analisis gender yang dapat digunakan untuk melakukan evaluasi program di masyarakat antara lain: (1) Teknik Analisis Harvard. (2) Teknik analisis Moser. (3) Teknik analisis Longwe. (4) Teknik analisis Munro. (5) Teknik Capasities and Vulnerabilities Analisys (CVA). (6) Matriks analisis Gender (Gender Analisys Matrix GAM). (7) Matrik kerangka kerja logik (The Logical Framework Matrix Longframe).

Konsep SEAGA. (9) Kerangka analisis gender analisys pathway (GAP). Pada teknik analisis Moser oleh Caroline Moser dikutip dalam (Novia Indah Lestari, 2015) menyatakan terdapat enam alat yang dapat digunakan, (1) Identifikasi peranan gender berdasarkan peran gender yang meliputi fungsi produktif, reproduktif, dan kemasyarakatan atau kerja sosial. (2) Penilaian kebutuhan gender yang meliputi pemenuhan kebutuhan praktis gender yang berkaitan dengan kebutuhan seharihari dan kebutuhan strategis gender. (3) Data pilah gender atau pemisahan data atau informasi berdasarkan jenis kelamin. (4) Menyeimbangkan peran gender antara laki-laki dan perempuan dalam mengelola kegiatan dan tugas-tugas produktif, reproduktif, serta sosial atau kemasyarakatan. (5) Matriks kebijakan WID (Women in Development) dan GAD (Gender and Development) untuk memberikan masukan mengenai pengarusutamaan gender. (6) Pelibatan stakeholder meliputi organisasi perempuan dan institusi lain dalam penyadaran gender pada perencanaan pembangunan.

Berdasarkan data pada penyaluran pembiayaan laki-laki cenderung lebih diuntungkan atas perempuan hal tersebut didasarkan pada, (1) Belum adanya komitmen dari lembaga keuangan mikro untuk menjadikan keadilan gender sebagai mainstream (arus utama) dalam penyaluran pembiayaan mikro, beberapa kasus seperti di negara Uganda diberikan anggaran untuk melakukan perubahan seperti insentif pada petugas yang manyalurkan pembiayaan secara adil (Labie et al., 2015). (2) Terdapat paradok dimana perempuan dipercaya sebagai pihak yang amanah dalam membayar kembali pembiayaan serta pihak yang rajin menabung secara reguler namun penyaluran pembiayaan semakin besar justru porsi perempuan semakin mengecil. (3) Diperlukan data pilah gender yang akurat dan memudahkan agar porsi keseimbangan penyaluran pembiayaan dapat dilakukan. Terdapat pemisahan nasabah laki-laki dan perempuan namun tidak terdapat menu untuk memudahkan 
melakukan sorting nasabah berdasarkan jenis kelamin. Sehingga bisa dikatakan sangat kesulitan untuk mendapatkan data. Tidak ada pemisahan dan perbandingan yang mudah didapatkan antara penerima manfaat pembiayaan laki-laki atau perempuan. (4) Program-program pembiayaan mikro belum mempertimbangkan bahwa waktu para perempuan telah sangat terbatas untuk berbagai aktivitas domestik rumah tangga. Perempuan menghadapi triple burden of women, yaitu perempuan harus melakukan tiga fungsi ganda berupa reproduksi, produksi dan sosial di masyarakat. Istilah ini mengacu kepada peran dan posisi perempuan dan posisi laki-laki. Subordinasi perempuan berawal dari pembagian kerja berdasarkan gender dan dihubungkan dengan fungsi perempuan sebagai ibu. Kemampuan perempuan ini digunakan sebagai alasan untuk membatasi perannya hanya pada peran domestik dan pemeliharaan anak.

\section{KESIMPULAN}

Berdasarkan data dan pembahasan dapat disimpulkan bahwa LKMS perlu untuk melakukan pengarusutamaan kesetaraan dan keadilan gender dan penyaluran pembiayaan yang inklusif dalam kebijakan penyaluran pembiayaan mikronya melalui aturan yang, (1) Menjadikan keadilan gender (gender equity) dan inklusi sosial sebagai salah satu indikator keberhasilan organisasi dan keberhasilan officer pembiayaan. (2) Mempermudah akses untuk data pilah gender dan penyandang disabilitas guna keseimbangan aksesibilitas perempuan dan penyandang disabilitas melalui perubahan sistem informasinya sehingga mempermudah sorting data anggota berdasarkan gender dan difabel dan non difabel. (3) Penyediaan akses anggaran guna mendukung kebijakan pengarusutamaan gender. (4) Dikarenakan dalam kasus penyaluran pembiayaan lebih menguntungkan laki-laki pada nominal pembiayaan yang lebih besar dan perempuan pada nominal pembiayaan yang lebih rendah dibandingkan laki-laki disebabkan adanya budaya patriarki para officer penyalur pembiayaan maka perlu dipertimbangkan adanya kemudahan akses perempuan untuk pembiayaan dengan nominal yang lebih besar melalui perubahaan kebijakan penyaluran pembiayaan. (5) Menghilangkan semua hambatan baik dalam regulasi maupun non regulasi pada pembiayaan kepada pihak pihak yang tereklusi dalam penyaluran pembiayaan mikro. Berdasarkan data dan pembahasan dapat disimpulkan bahwa LKMS perlu untuk melakukan pengarusutamaan kesetaraan dan keadilan gender dan penyaluran pembiayaan yang inklusif dalam kebijakan penyaluran pembiayaan mikronya melalui aturan yang, (1) Menjadikan keadilan gender (gender equity) dan inklusi sosial sebagai salah satu indikator keberhasilan organisasi dan keberhasilan officer pembiayaan. (2) Mempermudah akses untuk data pilah gender dan penyandang disabilitas guna keseimbangan aksesibilitas perempuan dan penyandang disabilitas melalui perubahan sistem informasinya sehingga mempermudah sorting data anggota berdasarkan gender dan difabel dan non difabel. (3) Penyediaan akses anggaran guna mendukung kebijakan pengarusutamaan gender. (4) Dikarenakan dalam kasus penyaluran pembiayaan lebih menguntungkan laki-laki pada nominal pembiayaan yang lebih besar dan perempuan pada nominal pembiayaan yang lebih rendah dibandingkan laki-laki disebabkan adanya budaya patriarki para officer penyalur pembiayaan maka perlu dipertimbangkan adanya kemudahan akses perempuan untuk pembiayaan dengan nominal yang lebih besar melalui perubahaan kebijakan penyaluran pembiayaan. (5) Menghilangkan semua hambatan baik dalam regulasi maupun non regulasi pada pembiayaan kepada 
pihak-pihak yang tereklusi dalam penyaluran pembiayaan mikro.

\section{DAFTAR PUSTAKA}

Addury, M. M. 2019. Impact of Financial Inclusion for Welfare: Analyze to Household Level. Journal of Finance and Islamic Banking, 1(2), p. 90.

Arunachalam, R. S. 2007. Microfinance and Innovative Financing for Gender Equality: Approaches, Challenges and Strategies Background paper prepared for the Commonwealth. Governance An International Journal of Policy And Administration.

Asmorowati, S. 2007. Dampak Pemberian Kredit Mikro untuk Perempuan: Analisis Pengadopsian Model Grameen Bank di Indonesia. Jurnal Masyarakat, Kebudayaan Dan Politik, 20(3), p. 175-190.

Bishwakarma, M. B. 2017. Social Inclusion through Microfinance: A Bottom Up Approach Social Inclusion through Microfinance: A Bottom Up Approach. Journal of Finance and Islamic Banking, 1(2), p. 90-104.

Burhan, B. 2012. Analisis Data Penelitian Kualitatif. Raja Grafindo Persada. Jakarta.

Dwipasari, L. 2016. Lending Model Bagi Usaha Mikro Pemula Dan. Jurnal Keuangan Dan Perbankan, 20(2), p. 314-321.

Hussain, J., Mahmood, S., \& Scott, J. 2019. Gender, Microcredit and Poverty Alleviation in a Developing Country: The Case of Women Entrepreneurs in Pakistan. Journal of International Development, 31(3), $\mathrm{p}$. 247-270.

Kusdarini, E. 2010. Keadilan Dan Kesetaraan Gender Dalam Pandangan Hukum Islam. di kuitp dari http://staff.uny.ac.id/sites/default/file s/pengabdian/eny-kusdarini-shmhum/ppm-keadilan-dan-kesetaraangender.pdf

Labie, M., Méon, P. G., Mersland, R., \& Szafarz, A. 2015. Discrimination by Microcredit Officers: Theory and Evidence on Disability in Uganda. Quarterly Review of Economics and Finance, 58, p. 44-55.

Novia Indah Lestari, I. A. 2015. Analisis Gender Dalam Program Simpan Pinjam Untuk Kelompok Perempuan (SPP). Sodality: Jurnal Sosiologi Pedesaan, 1(2), p. 112-130.

Nurdin, M. Fadhil. 2013. Eksklusi Sosial Dan Pembangunan Makna, Fokus dan Dimensi untuk Kajian Sosiologis. Analisis Pendapatan Dan Tingkat Kesejahteraan Rumah Tangga Petani, 53(9), p. 1689-1699.

Rachmina, D. 2009. Fenomena kesetaraan gender dalam kredit. Jurnal Agribisnis Dan Ekonomi Pertanian, 3(1), p. 1-18.

Rahman, M. M., Khanam, R., \& Nghiem, S. 2017. The Effects of Microfinance on Women's Empowerment: New Evidence from Bangladesh. International Journal of Social Economics, 44(12), p. 1745-1757.

Rantetana, M. 2011. Keuangan Mikro Untuk Menanggulangi Kemiskinan. GEMA PKM. Yogyakarta.

Robinson, Marguerite S. 2001. The Microfinance Revolution: Sustainable Finance for the Poor. The World Bank; Washington; D.C., p. 1-356.

Rodoni, Ahmad., Nengsih, Novia \& Supriyadi, Lilis. 2012. Financial Inclusion dan Financial Exclusion di Perbankan Syariah. Indo-Islamika, 6(2), p. 113-126. 
Sain, M. R. M., Rahman, M. M., \& Khanam, R. 2016. Financial exclusion in Australia: Can islamic finance minimise the problem? Australasian Accounting, Business and Finance Journal, 10(3), p. 89104.

Saravia-Matus, S., \& Saravia-Matus, J. 2012. Gender Issues in Microfinance and Repayment Performance: The Case of a Nicaraguan Microfinance Institution. Encuentro, 91, p. 7-31.

Sari, Kanthi Pamungkas \& Margowati, Sri. 2016. Analisis Harvard Pada Implementasi Program Kota Layak Anak. Cakrawala, XI(1), p. 116-129.

Setyari, N. P. W. 2012. Evaluasi Dampak Kredit Mikro Terhadap Kesejahteraan Rumah Tangga di Indonesia. Ekonomi Kuantitatif Terapan, 5(2), p. 141-150.

Suhra, S. 2013. Kesetaraan Gender Dalam Perspektif Al-Qur'an dan Implikasinya Terhadap Hukum Islam. Jurnal Al Ulum, Vol 13(2), p. 373-394.

Suryanto \& Zaenal, M. 2015. Potensi Lembaga Keuangan Mikro (Micro Finance) Dalam Pengembangan Perekonomian Jatinangor Menuju Masyarakat Ekonomi Asean (MEA) Tahun 2015. di kutip dari : http://pustaka.unpad.ac.id/wpcontent/uploads/2015/06/11pontensi-lembaga-keuanganmikro.pdf

Syukri Lukman, D. 2008. Kajian Upaya Penguatan Peran Microbanking dan Pendekatan Pembiayaan Kelompok dalam Rangka Pengembangan UMK. Center For Banking Research, p. 112.
Syukur, M. 2002. Analisis Keberlanjutan dan Perilaku Ekonomi Peserta Skim Kredit Rumahtangga Miskin. Institut Pertanian Bogor. Bogor. 